\title{
Changes in Regulating Ecosystem Services following Establishing Exclosures on Communal Grazing Lands in Ethiopia: A Synthesis
}

\author{
Wolde Mekuria \\ International Water Management Institute, P.O. Box 5689, Addis Ababa, Ethiopia \\ Correspondence should be addressed to Wolde Mekuria; w.bori@cgiar.org
}

Received 21 March 2013; Revised 23 May 2013; Accepted 27 May 2013

Academic Editor: Wen-Cheng Liu

Copyright ( 2013 Wolde Mekuria. This is an open access article distributed under the Creative Commons Attribution License, which permits unrestricted use, distribution, and reproduction in any medium, provided the original work is properly cited.

\begin{abstract}
In four separate studies undertaken in the northern highlands of Ethiopia, changes in regulating ecosystem services, economic viability, and the perception of local communities following establishing exclosures on communal grazing lands were investigated. Replicated $(n=3)$ 5-, 10-, 15-, and 20-year-old exclosures were selected and paired each exclosure with an adjacent grazing land. All exclosures displayed higher ecosystem services than communal grazing lands. Differences between exclosures and grazing lands varied between $29( \pm 4.9)$ and $61( \pm 6.7) \mathrm{Mg} \mathrm{Cha}^{-1}$ for ecosystem carbon stock (ECS), $2.4( \pm 0.6)$ and $6.9( \pm 1.8) \mathrm{Mg} \mathrm{ha}^{-1}$ for total soil $\mathrm{N}$ stock, and $17( \pm 3)$ to $39( \pm 7) \mathrm{Kg} \mathrm{ha}^{-1}$ for the available P stock, and all differences increased with exclosure duration. Differences in plant species richness and biomass between an exclosure age and communal grazing land were higher in oldest than in youngest exclosures. Over a period of 30 years, sequestered carbon dioxide was $246 \mathrm{Mg} \mathrm{ha}^{-1}$, total soil nitrogen increased by $7.9 \mathrm{Mg} \mathrm{ha}^{-1}$, and additional available phosphorous stocks amounted to $40 \mathrm{~kg} \mathrm{ha}^{-1}$. The Net Present Value of exclosures ecosystem services under consideration was about $28 \%$ (837 US\$) higher than alternative wheat production indicating that exclosures are competitive to alternative land uses. There are substantial opportunities to mobilize the local communities in efforts to establish exclosures, given that more than $75 \%$ had a positive view on exclosures effectiveness to restore degraded ecosystems. Establishing exclosures on communal grazing lands can be effective for restoring degraded ecosystems and the services that they provide.
\end{abstract}

\section{Introduction}

Land degradation, a decline of the biological or economic productivity of land resources resulting from land uses or processes arising from human activities, has a strong impact on ecosystem's services [1]. Land degradation may have impact on ecosystem's services through either land use conversion and/or inappropriate land management practices [2]. Land use conversion from one system to another may dramatically increase a particular ecosystem service, but often at the cost of reducing other services. The regulation services of ecosystem can be impaired by devegetation and vegetation degradation, deterioration of soil structure, loss of soil organic matter and organisms, and soil contamination [3].

As part of the efforts to restore degraded ecosystems and improve the services that they provide, communities in the highlands of Ethiopia started to establish exclosures on communal grazing lands about three decades ago [4].
Exclosures are areas closed to humans and domestic grazing animals with the goal of promoting natural regeneration of plants and reducing land degradation of formerly degraded communal grazing lands [4]. Exclosures are usually established in steep, eroded, and degraded areas that have been used for grazing in the past. The inception of exclosures dates back to the 1980s and coincided with the largescale land rehabilitation and soil and water conservation programs [5]. Priority areas for establishing exclosures are normally identified as a joint initiative of local communities, governmental and nongovernmental organizations $[4,6,7]$. Most importantly, development agents of BoARD and the "Baito" are involved in identifying areas to be closed. Final decisions are taken at a general meeting of the community [8]. Exclosure management and protection have proven to be effective because of the participation of the local communities in the establishment of exclosures and the responsibility of local authorities for management and control of the area $[6,7]$. Farmers' motivation for establishing exclosure and 
devising bylaws for managing exclosures in the northern highland of Ethiopia is deeply rooted in the political struggle of the Tigray People Liberation Front (TPLF) and follows a participatory process in most cases $[9,10]$. Awareness of the negative experiences in managing exclosures using topdown approaches in the "Derg" regime and the encouragement of TPLF towards empowering local governance have contributed to more participatory approaches to managing exclosures with locally devised bylaws. The area covered by exclosures in Tigray, for example, increased from 143,000 ha in 1996 to 262,000 ha in 2005 [5] and has increased further to 895,220 ha in 2011 [8]. The size of an exclosure ranges from as small as 1 ha up to 700 ha [5].

In terms of ecosystem services, exclosure land management contributes to provisioning ecosystem services through generation of animal feed and human food (e.g., honey; [11]); regulating services through below- and aboveground carbon sequestration (e.g., [4]) and soil erosion control [12]; supporting services through soil formation [11, 13], nutrient cycling, and biomass production [14]; and cultural services through generation of aesthetic value and use for educational purposes. This paper presents a synthesis of the regulating ecosystem services of exclosures based on four independent studies that are conducted in the northern highlands of Ethiopia.

Particularly, the objectives of the study are (1) to investigate how exclosure age affects ecosystem carbon sequestration (ECS) and soil and vegetation restoration in the northern highlands of Ethiopia, (2) to identify which easily measurable biophysical and management-related factors can be used to predict ECS, soil, and vegetation restoration in exclosures and in adjacent communal grazing lands, and (3) to assess the economic viability of exclosure land management and the perception of local communities on the effectiveness of exclosures to restore degraded soils and vegetation. It is hypothesized that (1) soil and plant biomass carbon and soil nutrients increase after establishment of exclosures on communal grazing lands, (2) these increases in soil and plant biomass carbon stocks and soil nutrient stocks can be predicted based on land use history, soil characteristics, and climatic parameters, and (3) exclosure establishment on degraded communal grazing lands yields substantial economic returns and their net benefit of restoring carbon and soil nutrients would be higher than that of the best alternative, that is, crop production.

\section{Methods}

2.1. Study Area. The study was conducted in four districts located in the highlands of Tigray $\left(12^{\circ}\right.$ to $15^{\circ} \mathrm{N}$ latitude and $36^{\circ} 30^{\prime}$ to $40^{\circ} 30^{\prime} \mathrm{E}$ longitude), the northernmost region of Ethiopia [14-16]. In the study area, the first exclosures were established three decades ago, and accordingly we selected replicated $(n=3)$ exclosures of $5,10,15$, and 20 years old that were adjacent to corresponding communal grazing lands. We assume that prior to establishment, exclosures and the adjacent grazing lands had similar conditions as the exclosures were established on the same communal grazing lands which were used for livestock grazing. The area of the exclosures ranged from 7.2 to 28.0 ha whereas the adjacent communal grazing lands ranged from 2.0 to 12.0 ha. Details of exclosure land management, climate, vegetation composition and the soils of the study sites are described in Mekuria et al. [4].

2.2. Experimental Design. A space-for-time substitution approach was used to monitor changes in ECS, soil properties and nutrients, and vegetation composition and diversity after conversion of communal grazing lands to exclosures with ages of $5,10,15$, and 20 years. The implicit assumption of this approach is that each paired grazing land and exclosure age should have comparable initial conditions such that changes in carbon stocks are a consequence of the land use change (i.e., exclosure establishment). Thus, we selected sites with a pair of communal grazing land and exclosure adjacent to each other, ensuring that soil and terrain conditions were as similar as possible between each pair. To cover the variability in soil and topography, we selected three replicates for each paired grazing land and exclosure age throughout the highlands of Tigray [4]. Landscape position was included in the sampling design to characterize the effects of topographyrelated processes on ECS. The upper slope position receives little or no overland flow but contributes runoff to downslope areas. The midslope position receives overland flow from the upper slope and contributes runoff to the footslope. The footslope receives overland flow and deposition from the upper and midslope positions [12]. Details of experimental design that are used for the assessment of ECS, soil properties, and vegetation composition and diversity were described in Mekuria et al. [14-16]. Soil, vegetation, and managementrelated data were collected from January to October 2008.

2.2.1. Soil and Vegetation Sampling, Analysis, and Carbon and Soil Nutrient Stock Calculation. We chose to sample soil from $0-0.2 \mathrm{~m}$ depth as most of the Tigray highlands are covered by soils with intermediate depth $(30$ to $60 \mathrm{~cm}$, Tigray Agricultural and Rural Development Bureau, unpublished data). Furthermore, studies conducted in forest ecosystems of the highlands of Ethiopia reported that more than $70 \%$ of total soil carbon is located in the top $20 \mathrm{~cm}$ depth (e.g., [17]). Vegetation parameters: diameter at breast height $(\mathrm{DBH})$, or for smaller and multistemmed shrub, diameter at stump height or at the height of $30 \mathrm{~cm}\left(\mathrm{~d}_{30}\right)$ from the ground, crown diameter, total height, and species identity were measured. $\mathrm{DBH}$ and $\mathrm{d}_{30}$ were measured using calipers. Crown diameter was measured using a measuring tape. Total height was measured using either a clinometer or a measuring tape depending on tree height. In the entire study, we examined 186 plots of which 105 were in exclosures and 81 in communal grazing lands. To undertake soil laboratory analyses, the samples collected from each landscape position per replicate (i.e., 50 to 75 random sampling points from 2 to 3 transects) were mixed thoroughly in a large bucket to form one composite soil sample. In the entire study, we collected a total number of 72 composite soil samples (i.e., (2 (paired exclosure and grazing land) $\times 4$ age classes $\times 3$ landscape positions $\times 3$ replications) $=72$ ). Details of soil and vegetation sampling and analyses can be found in Mekuria et al. [14-16]. 
Soil organic carbon and soil nutrient stocks in the $0-0.2 \mathrm{~m}$ depth were calculated as follows:

$$
\begin{aligned}
\operatorname{SOC}\left(\mathrm{MgCha}^{-1}\right)= & \left(\frac{\% \mathrm{C}}{100}\right) \times \mathrm{Bd}\left(\mathrm{Mg} \mathrm{m}^{-3}\right) \\
& \times \operatorname{depth}(\mathrm{m}) \\
& \times 10000 \mathrm{~m}^{2} \mathrm{ha}^{-1} \\
\mathrm{~N}\left(\mathrm{Mg} \mathrm{Nha}^{-1}\right)= & \left(\mathrm{N}(\%) \times 10^{-2}\right) \\
& \times \mathrm{Bd}\left(\mathrm{Mg} \mathrm{m}^{-3}\right) \\
& \times \operatorname{depth}(\mathrm{m}) \\
& \times 10000 \mathrm{~m}^{2} \mathrm{ha}^{-1}, \\
\text { Olsen-P }\left(\mathrm{Mg} \mathrm{Pha}^{-1}\right)= & \left(\mathrm{P}(\mathrm{ppm}) \times 10^{-6}\right) \\
& \times \mathrm{Bd}\left(\mathrm{Mg} \mathrm{m}^{-3}\right) \\
& \times \operatorname{depth}\left(\mathrm{m}^{-3}\right. \\
& \times 10000 \mathrm{~m}^{2} \mathrm{ha}^{-1},
\end{aligned}
$$

where SOC, N, Olsen-P, and Bd are soil organic carbon, total soil $\mathrm{N}$, available $\mathrm{P}$, and bulk density, respectively. The average bulk density of the oldest exclosure was used to calculate soil organic carbon, total soil $\mathrm{N}$, and available $\mathrm{P}$ stocks in all exclosures and grazing lands. We used this conservative approach to avoid overestimation of the soil organic carbon, total soil $\mathrm{N}$, and available $\mathrm{P}$ stocks due to changes in bulk density [18].

To determine the species similarities between exclosures and grazing lands, Sorensen's similarity index [19] was used. To determine native plant species diversity in exclosures and grazing lands and to conduct comparisons in species diversity between exclosures and adjacent grazing lands, the Shannon-Wiener index of diversity $\left(H^{\prime}\right)$ [20] was used. To determine the similarity in abundance of different species within a community, the Shannon-Wiener index of evenness $(J)$ was used. To estimate aboveground biomass, the dominant woody species using our inventory data were identified. The dominant woody species were determined based on the relative importance value (i.e., the sum of relative basal area, relative frequency, and relative density) in each exclosure and adjacent grazing land. The methods of [21] and [22] were used for aboveground woody biomass measurement. Further details of vegetation sampling and analyses as well as aboveground biomass estimation can be found in Mekuria and Veldkamp [14].

2.2.2. Assessment of Local Communities' Perception and Economic Valuation. To assess local communities' perception on the effectiveness of exclosures to restore degraded soils and vegetation, a socioeconomic survey was conducted from February to July of 2008 using a structured survey questionnaire. Details of the sampling technique and sample size can be found in Mekuria et al. [4]. As certified emission reductions (CERs) are traded as $\mathrm{CO}_{2}$ units [23] carbon storage was converted into $\mathrm{CO}_{2}$ quantities $\left(\mathrm{MgCO}_{2} \mathrm{ha}^{-1}\right)$ multiplying carbon storage $\left(\mathrm{Mg} \mathrm{C} \mathrm{ha}^{-1}\right)$ by the molar conversion factor of 3.67 [24]. For determining carbon revenues, we transformed permanent carbon prices into prices for temporary credits in accordance with Olschewski et al. [24]. To determine the additional exclosure benefits from soil nutrients restoration, we applied a cost-based value method according to [25]. We estimated the increase in soil total nitrogen and phosphorous stocks $\left(\mathrm{Mg} \mathrm{ha}^{-1}\right)$ due to exclosures establishment and multiplied the additional stocks by the local market prices of nitrogen and phosphorous fertilizers to get the economic value in monetary terms.

We conducted a financial analysis of costs and benefits using market prices for valuing project impacts. Given the long-term project horizon, costs and benefits occurring at different points of time were discounted to make them comparable. For this purpose, real discount rate $r$ was determined based on price index and interest rate information of recent consecutive years. Details of the financial analysis can be found in [4].

2.3. Statistical Analyses. First tests for normality (Kolmogorov-Smirnov D statistic) and equality of variance (Levene statistic) of soil organic carbon and aboveground carbon stocks, soil properties, and nutrient and vegetation composition and diversity were conducted. The differences among landscape positions in soil and vegetation variables under consideration for each exclosure age and communal grazing lands were tested using one-way analysis of variance (ANOVA). The differences in soil properties, carbon stocks, and vegetation composition between an exclosure age and adjacent communal grazing land were assessed at each landscape position using a paired $t$-test. The patterns of changes in carbon stocks (i.e., difference between an exclosure age and adjacent grazing lands) across exclosure ages $(5,10,15$, and 20 years) were assessed using one-way ANOVA with Tukey HSD test. Pearson correlation tests were conducted to examine the relationships between dependent and independent variables using the mean values of the three landscape positions for each land use type $(n=12)$. Finally, stepwise multiple regression analyses were done to establish predictive relationships between carbon and soil nutrient stocks and easily measurable independent variables. The best predictive variables were selected using forward stepwise procedure that uses a sequence of $F$-tests. Colinearity among the input predictive variables used in the regression models was not detected.

\section{Results}

3.1. Ecosystem Carbon Stocks in Exclosures and Adjacent Communal Grazing Lands. We did not detect differences among landscape positions $(P>0.05)$ in soil and aboveground carbon stocks within any of the exclosure ages and adjacent grazing lands. At each landscape position, exclosures showed higher soil carbon concentration, soil carbon stocks, and 


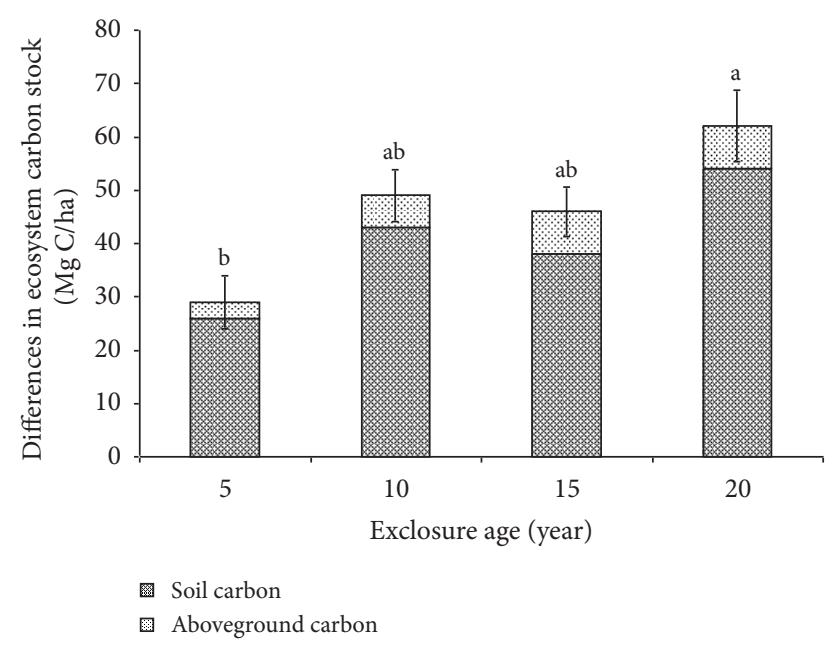

FIGURE 1: Differences in ecosystem carbon stocks between paired exclosures and adjacent communal grazing lands in relation to exclosure age. Means ( $n=3$; SE bars) followed by different letters indicate significant differences among exclosure ages (oneway ANOVA with Tukey HSD at $P \leq 0.05$ ) (source [4]).

aboveground carbon stocks than the adjacent grazing lands (Table 1). The difference between exclosures and adjacent grazing lands in soil carbon stock, averaged across landscape positions at each exclosure age, ranged from 26.0 to $53.7 \mathrm{MgC} \mathrm{ha}^{-1}$ whereas in aboveground carbon stock varied between 2.0 and $7.0 \mathrm{Mg} \mathrm{Cha}^{-1}$. These values translated to soil carbon stock increase of $41 \%$ to $60 \%$ and to aboveground carbon stock increase of $83 \%$ to $87 \%$ following conversion of degraded grazing lands to exclosures. Soil carbon stock contributed most of the increase in ECS (ranging from $83 \%$ to $90 \%)$ compared to aboveground carbon in exclosures (Table 1). Woody biomass carbon consistently increased with exclosure age while grass biomass carbon slightly decreased (Table 1). The influence of exclosure age on ECS was not linear with time as the increase in ECS was only significant between 5-year and 20-year exclosures (Figure 1).

\subsection{Soil Nutrient Content and Soil Properties in Exclosures} and Adjacent Grazing Lands. We did not detect differences among landscape positions $(P>0.05)$ in soil nutrient content and properties within any of the exclosure ages and adjacent grazing lands, suggesting that landscape position was not a significant conditioning factor affecting soil nutrient content and soil properties. At each landscape position, exclosures showed significantly higher soil total $\mathrm{N}$ content, available $\mathrm{P}$ content, and CEC than the adjacent grazing lands (Table 2).

The difference in soil properties between exclosures and adjacent grazing lands in the $0-0.2 \mathrm{~m}$ depth, averaged across landscape positions at each exclosure age, varied between 2.4 $( \pm 0.61)$ and $6.9( \pm 1.85) \mathrm{Mg} \mathrm{ha}^{-1}$ for total $\mathrm{N}$ stocks, from 17 $( \pm 3)$ to $39( \pm 7) \mathrm{kg} \mathrm{ha}^{-1}$ for available P stocks, and between $13.0( \pm 1.2)$ and $20.4( \pm 2.8)$ for CEC. These values translated to an increase of $28 \%-48 \%$ for soil total N stocks, $26 \%-$ $39 \%$ for available P stocks, and $47 \%-71 \%$ for CEC following conversion of degraded grazing lands to exclosures. The influence of exclosure age on soil total $\mathrm{N}$, available $\mathrm{P}$ stocks and CEC was not linear with time as the increase in soil total $\mathrm{N}$ and available $\mathrm{P}$ stocks was only significant between 5year and 20-year old exclosures, and we observed marginally significant differences $(P=0.058)$ in CEC between 5 -year and 20-year-old exclosures (Figures 2(a), 2(b), and 2(c)).

\subsection{Vegetation Composition in Exclosures and Communal} Grazing Lands. In exclosures, we recorded between 33 and 85 plant species representing 21 to 48 families whereas we recorded between 8 and 25 plant species representing 8 to 19 families in the adjacent communal grazing lands (Table 3 ). The oldest exclosures contained more plant families that were represented by two or more species. In all exclosures, Fabaceae/Leguminosae and Poaceae contributed the greatest number of species. Exclosures contained more herbaceous, shrub, and tree species than the adjacent communal grazing lands (Table 4). Moreover, the number of herbaceous and tree species increased with exclosure age. The similarity of vegetation between an exclosure and the adjacent communal grazing land varied between $41.3 \%( \pm 7.2)$ and $54.2 \%( \pm 10.5)$ and decreased with exclosure age. The number of tree species found only in exclosures showed a consistent increase with exclosure age. However, the proportion of herbaceous and shrub species was considerable (ranging from $83 \%$ in the 5 year-old exclosures to $74 \%$ in the 20 -year-old exclosures). Furthermore, we recorded higher numbers of economically important indigenous shrub and tree species (i.e., shrub and tree species that can be used by the local communities as sources of fuel wood and construction materials) in exclosures compared to the adjacent communal grazing lands (Table 4). The proportion of economically important indigenous shrub and tree species recorded in all exclosures was considerable and varied between 35 and $43 \%$ of the total number of shrub and tree species. The number of legumes recorded in the exclosures varied between $2.0( \pm 0.6$; i.e., $10 \%$ of the total species recorded) and $4.0( \pm 0.6$; i.e., $13 \%)$ and increased with exclosure age.

3.4. Species Richness and Diversity in Exclosures and Communal Grazing Lands. All exclosures displayed higher plant species richness and diversity compared to the adjacent communal grazing lands (Table 4 ). The 20 -year-old exclosure displayed the highest proportional increase in plant species richness following establishment (i.e., 63\% increase compared to the adjacent grazing land). Significant differences in the increases in plant species richness and diversity among landscape positions were not detected $(P>0.05)$ within any of the exclosure ages or the adjacent communal grazing lands. However, within exclosures, the upper slopes positions had consistently higher plant species richness and diversity.

3.5. Soil, Vegetation, and Climatic Variables Explaining Ecosystem Carbon Stocks and Soil Properties. Soil carbon stocks in exclosures and their difference from adjacent grazing lands were positively correlated with clay content $(r=0.74$ and 0.75, resp.; $P<0.05$ ), precipitation $(r=0.86,0.70)$, woody 
TABLE 1: Mean values $(n=3, \pm \mathrm{SE})$ of aboveground carbon stocks $\left(\mathrm{MgC} \mathrm{ha}^{-1}\right)$ and soil carbon stocks $\left(\mathrm{Mg} \mathrm{Cha}^{-1}\right)$ in the $0-0.2 \mathrm{~m} \mathrm{depth}$ in paired exclosures and adjacent communal grazing lands.

\begin{tabular}{|c|c|c|c|c|c|c|c|}
\hline \multirow{2}{*}{ Exclosure duration } & \multirow{2}{*}{ Landscape position } & \multicolumn{2}{|c|}{ Exclosure } & \multicolumn{2}{|c|}{ Grazing land } & \multicolumn{2}{|c|}{ Difference } \\
\hline & & Soil C & Woody C & Soil C & Woody C & Soil C & Woody C \\
\hline \multirow{3}{*}{5} & Upper slope & $62.5(3.4)$ & $2.0(0.6)$ & $35.8(3.2)$ & $0.44(0.2)$ & $26.7(3.7)^{* *}$ & $1.56(0.4)^{*}$ \\
\hline & Mid slope & $59.4(6.2)$ & $1.8(0.5)$ & $41.7(7.0)$ & $0.30(0.1)$ & $17.7(2.4)$ & $1.50(0.6)^{*}$ \\
\hline & Foot slope & $68.8(5.4)$ & $3.1(0.1)$ & $35.3(2.7)$ & $0.41(0.1)$ & $33.5(6.7)^{* *}$ & $2.69(0.2)^{* *}$ \\
\hline \multirow{3}{*}{10} & Upper slope & $73.3(7.4)$ & $8.3(2.0)$ & $31.2(7.6)$ & $0.48(0.1)$ & $42.1(6.5)^{*}$ & $7.82(1.7)^{*}$ \\
\hline & Mid slope & $69.6(10.0)$ & $4.7(0.6)$ & $24.2(0.5)$ & $0.57(0.1)$ & $45.4(9.5)^{*}$ & $4.13(0.6)^{* *}$ \\
\hline & Foot slope & $70.1(6.1)$ & $3.5(0.3)$ & $28.4(3.0)$ & $0.69(0.2)$ & $41.7(7.6)^{* *}$ & $2.81(0.5)^{* *}$ \\
\hline \multirow{3}{*}{15} & Upper slope & $69.4(7.9)$ & $7.1(2.0)$ & $31.9(3.6)$ & $0.07(0.0)$ & $37.5(6.1)^{*}$ & $7.03(2.8)^{*}$ \\
\hline & Mid slope & $68.6(7.8)$ & $6.6(1.1)$ & $33.4(1.9)$ & $0.06(0.0)$ & $35.2(6.3)^{*}$ & $6.54^{* *}(1.1)$ \\
\hline & Foot slope & $78.6(2.0)$ & $8.1(0.3)$ & $36.6(25)$ & $0.09(0.0)$ & $42(3.6)^{* *}$ & $8.01(0.3)^{* *}$ \\
\hline \multirow{3}{*}{20} & Upper slope & $92.7(8.7)$ & $8.8(2.0)$ & $41.8(8.5)$ & $1.20(0.2)$ & $50.9(6.6)^{*}$ & $7.60(2.6)^{*}$ \\
\hline & Mid slope & $81.4(12.7)$ & $5.8(0.9)$ & $38.5(4.6)$ & $0.98(0.1)$ & $42.9(8.1)^{*}$ & $4.82(1.5)^{*}$ \\
\hline & Foot slope & $106.8(6.4)$ & $9.3(2.5)$ & $39.4(4.3)$ & $1.02(0.2)$ & $67.4(5.6)^{* *}$ & $8.28(2.1)^{*}$ \\
\hline
\end{tabular}

${ }^{\ddagger}$ Differences in soil carbon concentration, soil carbon stocks, and woody biomass carbon stocks (calculated as: exclosure - adjacent grazing land) were significant at ${ }^{*} P<0.05,{ }^{* *} P<0.01$ (paired $t$-test).

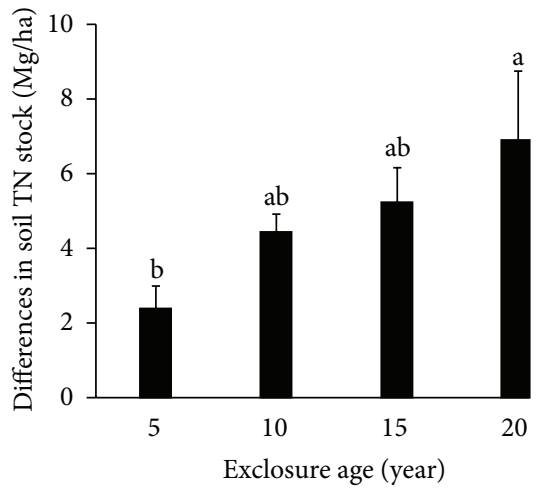

(a)

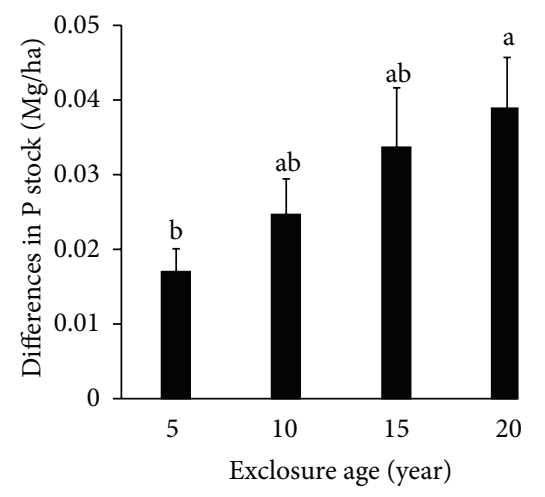

(b)

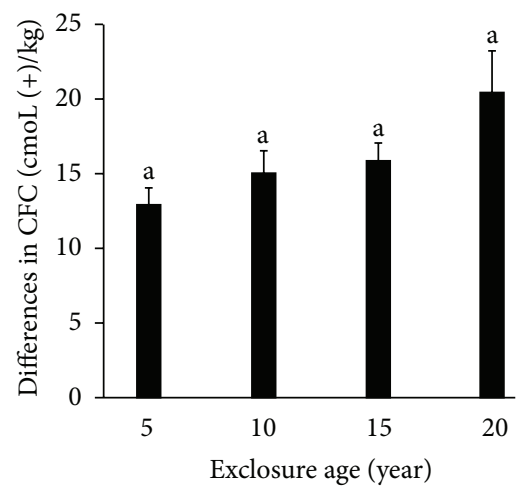

(c)

FIGURE 2: Differences between exclosures and adjacent communal grazing lands in total soil N stock (a), available P stock (b), and CEC (c) in relation to exclosure age. Means $(n=3$, SE bars) followed by different letters in the same graph indicate significant differences among categories of exclosure age (one-way ANOVA with Kruskal-Wallis test at $P \leq 0.05$ ).

biomass $(r=0.77,0.77)$, vegetation canopy cover $(r=0.80$, $0.66)$ and exclosure age $(r=0.62,0.75)$ and were inversely correlated with bulk density $(r=-0.61,-0.56)$, stone cover $(r=-0.70,-0.45)$ and slope $(r=-0.48,-0.69 ; P<0.05)$. Aboveground carbon stocks in exclosure and their differences from adjacent grazing lands were positively correlated with clay content $(r=0.67,0.62$, resp.; $P<0.05)$, precipitation $(r=0.64,0.55)$, vegetation canopy cover $(r=0.81,0.77)$, and exclosure age $(r=0.75,0.77)$ and were inversely correlated with bulk density $(r=-0.81,-0.82)$. In grazing lands, soil carbon stocks were only positively correlated with soil $\mathrm{pH}$ $(r=0.66)$ and vegetation canopy cover $(r=0.59)$, whereas aboveground carbon stocks correlated with clay content $(r=$ $0.55)$ and precipitation $(r=0.72)$.

Soil total $\mathrm{N}$ and available $\mathrm{P}$ concentrations and stocks as well as CEC in exclosures and their differences from adjacent grazing lands were positively and significantly $(P<0.05)$ correlated with woody biomass, vegetation canopy cover, clay content, precipitation, and exclosure age but were inversely correlated with bulk density. In grazing lands, soil total $\mathrm{N}$ concentration and stock did not show significant positive and significant negative correlations with the independent variables. Available P stock and CEC were positively correlated only with vegetation canopy cover.

3.6. Revenues from Ecological Services of Exclosures and Crop Production. The ecosystem $\mathrm{CO}_{2}$ storage in exclosures increased with exclosure duration: $247 \mathrm{Mg} \mathrm{CO}_{2} \mathrm{ha}^{-1}$ in the 5year-old exclosure, 285 in the 10 -year-old exclosure, 296 in the 15 -year-old exclosure, and 376 in the 20 year-old exclosure. For the calculation of the benefit flows over a 30 years period, we assumed a constant amount of ecosystem carbon storage after 20 years. For calculating the amount of temporary certificates the baseline $\mathrm{CO}_{2}$ storage of $130 \mathrm{Mg} \mathrm{ha}^{-1}$ was subtracted, resulting in temporary certified emission reduction (tCER) unit, of $117 \mathrm{MgCO}_{2} \mathrm{ha}^{-1}$ after 5 years, 


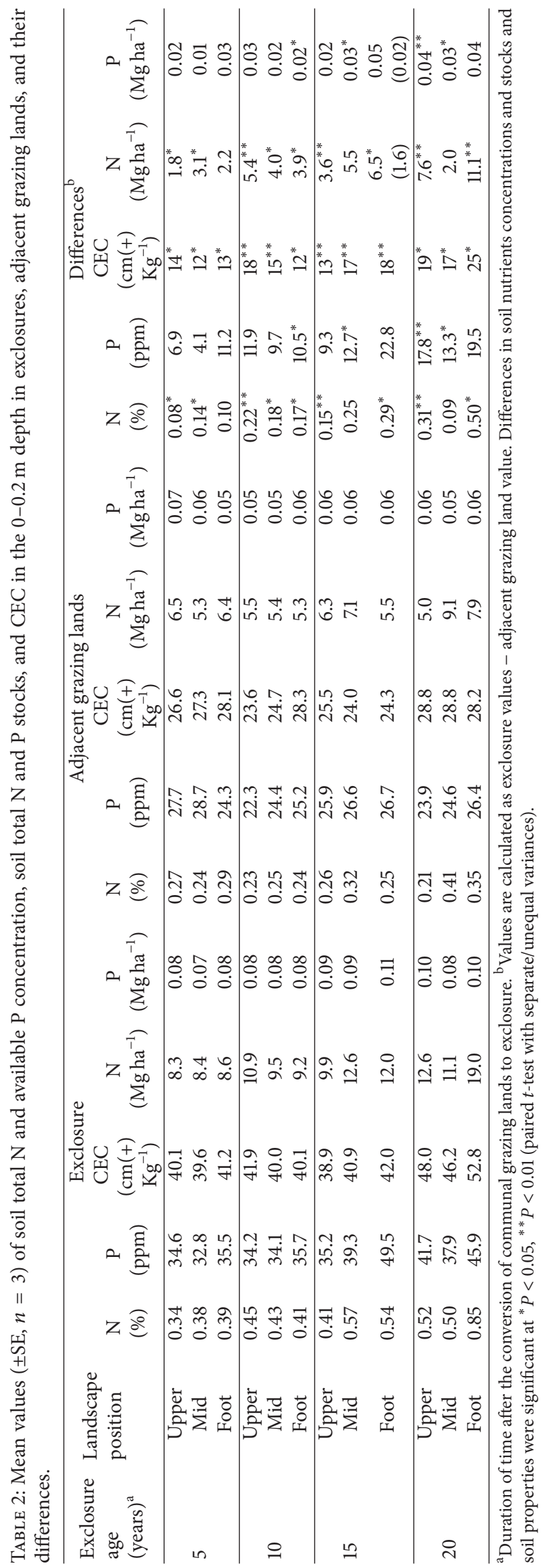


TABLE 3: Total number of native plant species recorded in the entire sampled plots in exclosures, grazing lands, and church forests.

\begin{tabular}{|c|c|c|c|c|}
\hline Variables & Exclosure age (year) & Exclosures & Adjacent grazing lands & Church forests \\
\hline \multirow{4}{*}{ Total number of sampled plots } & 5 & 24 & 24 & 24 \\
\hline & 10 & 27 & 15 & \\
\hline & 15 & 24 & 18 & \\
\hline & 20 & 27 & 24 & \\
\hline \multirow{4}{*}{ Area of the total sampled plots (ha) } & 5 & 0.96 & 0.96 & 0.96 \\
\hline & 10 & 1.08 & 0.60 & \\
\hline & 15 & 0.96 & 0.72 & \\
\hline & 20 & 1.08 & 0.96 & \\
\hline \multirow{4}{*}{ Total number of species recorded } & 5 & 48 & 13 & 59 \\
\hline & 10 & 33 & 8 & \\
\hline & 15 & 53 & 15 & \\
\hline & 20 & 85 & 25 & \\
\hline \multirow{4}{*}{ Plant families (number) } & 5 & 30 & 11 & 36 \\
\hline & 10 & 21 & 8 & \\
\hline & 15 & 30 & 12 & \\
\hline & 20 & 48 & 19 & \\
\hline \multirow{4}{*}{ Families represented by two or more species (number) } & 5 & 12 & 2 & 13 \\
\hline & 10 & 8 & 0 & \\
\hline & 15 & 13 & 3 & \\
\hline & 20 & 18 & 5 & \\
\hline
\end{tabular}

155 after 10 years, 166 after 15 years, 246 after 20 and 25 years each (Table 5). Note that the last credits are issued in year 25 expiring at the end of the project. Similar to the tCER units calculation, the change in total soil nitrogen and available phosphorous stocks after the establishment of exclosures on degraded communal grazing lands was determined. As a result, the Net Present Value (NPV) of the exclosures' ecological services amounts to 3071 US \$ ha ${ }^{-1}$ and by far exceeds the economic outcome of alternative crop production, such as wheat, barley, and teff (Table 6). Carbon sequestration contributes about $30 \%$ to NPV, while soil nutrient storage accounts for about $70 \%$. Interestingly, discounted carbon revenues (to be generated by Clean Development Mechanisms (CDM) projects) make up for about $44 \%$ of the NPV of the best alternative land use (wheat production). The ecological results are summarized in Table 5, while the outcome of the economic analysis is given in Table 6 .

\subsection{Perception of Local Communities on the Effectiveness of} Exclosures to Restore Degraded Soils and Vegetation. The results of the survey showed that there are different perceptions of the local communities concerning the effectiveness of exclosures to restore degraded soils and vegetation (Figure 3 ). The majority of the respondents (52\%) have the opinion that exclosures are highly effective to promote vegetation restoration. Several respondents elaborate that degraded indigenous shrub and tree species are restored after the establishment of exclosures. However, $28 \%$ of respondents rank the effectiveness of exclosures to promote vegetation restoration as medium due to the fact that the restored vegetation is dominated by Acacia species. Furthermore, 28\% of the respondents suggest that exclosures should be supported by planting of fast growing indigenous tree species to increase resource availability for fuel wood and construction materials. The majority (52\%) of the respondents' evaluate exclosures as highly effective to improve soil fertility because they observed increased sediment accumulation and organic input in exclosures due to growth of grasses and shrubs. Only small differences in the perception of respondents living near and far from exclosures on the effectiveness of exclosures to restore degraded soils and vegetation were observed.

Although most of the respondents have a positive perception of exclosures' benefits related to the restoration of degraded soils and vegetation (Figure 3), some drawbacks of exclosures establishment are pointed out, $64 \%$ of respondents mentioned that exclosures have a negative effect on fuel wood availability. Additionally, 58\% of the respondents are concerned that exclosures cause a shortage of grazing area leading to a reduced number of livestock holding by the local communities, which consequently has negative impact on their livelihood.

\section{Discussion}

The improvement of soil and vegetation carbon stocks, soil properties, and vegetation composition in all exclosures indicate that exclosures have a significant positive effect on the restoration of degraded ecosystems and enhancement of regulating ecosystem services that they provide, even in highly degraded communal grazing lands. Several other studies conducted in the highlands of Ethiopia and elsewhere in the world have shown that exclosures have a positive 
TABLE 4: Average ( \pm SE, $n=3$ ) of species composition and diversity in exclosures and communal grazing lands and their differences.

\begin{tabular}{|c|c|c|c|c|c|}
\hline Variables & Exclosure age (year) & Exclosures & Adjacent grazing lands & Differences $^{\mathrm{a}}$ & $P$ value $^{\mathrm{b}}$ \\
\hline \multirow{4}{*}{ Richness $^{c}$ (number) } & 5 & $20.0(1.7)$ & $10.0(0.3)$ & 10.0 & 0.01 \\
\hline & 10 & $15.7(1.8)$ & $6.7(4.1)$ & 9.0 & 0.11 \\
\hline & 15 & $30.0(6.8)$ & $10.7(2.7)$ & 19.3 & 0.02 \\
\hline & 20 & $31.3(4.2)$ & $11.7(4.8)$ & 19.6 & 0.03 \\
\hline \multirow{4}{*}{ Diversity (Shannon-Wiener index) } & 5 & $1.4(0.1)$ & $1.3(0.1)$ & 0.1 & 0.17 \\
\hline & 10 & $1.4(0.1)$ & $0.7(0.2)$ & 0.7 & 0.01 \\
\hline & 15 & $2.0(0.1)$ & $0.9(0.2)$ & 1.1 & 0.00 \\
\hline & 20 & $2.1(0.1)$ & $1.4(0.2)$ & 0.7 & 0.00 \\
\hline \multirow{4}{*}{ Evenness (Shannon-Wiener index) } & 5 & $0.56(0.04)$ & $0.78(0.03)$ & -0.22 & 0.01 \\
\hline & 10 & $0.67(0.03)$ & $0.41(0.10)$ & 0.26 & 0.00 \\
\hline & 15 & $0.67(0.03)$ & $0.58(0.12)$ & 0.09 & 0.44 \\
\hline & 20 & $0.72(0.05)$ & $0.73(0.04)$ & -0.01 & 0.13 \\
\hline \multirow{4}{*}{ Herbaceous species (number) } & 5 & $2.7(0.3)$ & $0.7(0.3)$ & 2.0 & 0.01 \\
\hline & 10 & $2.0(1.2)$ & $1.3(0.9)$ & 0.7 & 0.67 \\
\hline & 15 & $3.0(0.6)$ & $0.7(0.3)$ & 2.3 & 0.02 \\
\hline & 20 & $4.7(1.5)$ & $1.3(0.9)$ & 3.3 & 0.12 \\
\hline \multirow{4}{*}{ Shrub species (number) } & 5 & $10.3(1.7)$ & $5.3(0.7)$ & 5.0 & 0.04 \\
\hline & 10 & $7.7(0.9)$ & $3.7(2.3)$ & 4.0 & 0.18 \\
\hline & 15 & $15.7(1.8)$ & $6.3(1.7)$ & 9.3 & 0.01 \\
\hline & 20 & $14.7(1.8)$ & $6.7(2.2)$ & 8.0 & 0.04 \\
\hline \multirow{4}{*}{ Tree species (number) } & 5 & $4.0(0.6)$ & $2.0(0.6)$ & 2.0 & 0.07 \\
\hline & 10 & $4.0(0.6)$ & $1.0(0.6)$ & 3.0 & 0.02 \\
\hline & 15 & $8.0(3.1)$ & $2.7(0.7)$ & 5.3 & 0.16 \\
\hline & 20 & $8.0(1.0)$ & $3.0(1.0)$ & 5.0 & 0.02 \\
\hline \multirow{4}{*}{ Economically important species (number) } & 5 & $6.3(0.9)$ & $2.7(0.9)$ & 3.7 & 0.04 \\
\hline & 10 & $5.0(1.0)$ & $2.0(0.6)$ & 3.0 & 0.06 \\
\hline & 15 & $9.0(2.1)$ & $4.0(1.5)$ & 5.0 & 0.12 \\
\hline & 20 & $8.0(1.0)$ & $2.7(1.2)$ & 5.3 & 0.03 \\
\hline
\end{tabular}

${ }^{a}$ Differences are calculated as exclosure values minus adjacent grazing land values. Differences in species richness are equivalent to the value of beta diversity provided that we did not encounter a species unique to the communal grazing lands. ${ }^{\mathrm{b}}$ The $P$ values are values obtained after paired $t$-test. ${ }^{\mathrm{c}}$ Richness refers the total number of plant species in an area including forbs, lianas, and grasses.

effect in improving regulating ecosystem services such as soil and aboveground carbon sequestration (e.g., [6, 26, 27]); restoration of soil nutrient content and properties (e.g., [28, 29]); restoration of vegetation composition and improvement of species diversity and richness (e.g., [30-36]).

The sizeable differences in regulating ecosystem services between exclosures and communal grazing lands can be explained in two ways. On one hand, increased grazing pressure in the reduced area of communal grazing lands after establishment of exclosures and susceptibility to erosion due to sparse vegetation cover would cause further decrease in regulating ecosystem services in grazing lands. On the other hand, increased vegetation cover in exclosures would reduce erosion and increase organic matter input into the soil. For example, Descheemaeker et al. [7] reported an increase of leaf-, woody-, and reproductive organs-litter input from $20 \mathrm{~g} \mathrm{~m}^{-2}$ in degraded grazing lands to nearly $600 \mathrm{~g} \mathrm{~m}^{-2}$ in $20-$ year-old exclosures. Comparing our estimated ECS increase (e.g., $3.1 \mathrm{MgCha}^{-1} \mathrm{yr}^{-1}$ under 20 year exclosure; Figure 1) after exclosure establishment with the soil carbon loss due to water erosion from grazing lands $\left(0.075 \mathrm{MgC} \mathrm{ha}^{-1} \mathrm{yr}^{-1}\right.$; [26]) and fuel wood consumption $\left(0.31 \mathrm{MgC} \mathrm{ha}^{-1} \mathrm{yr}^{-1} ;[37,38]\right)$, the considerable differences in regulating ecosystem services between exclosures and grazing lands were largely due to the effect of exclosure land management in enhancing organic carbon input, soil erosion control, and vegetation restoration.

Improvements of regulating ecosystem services were also influenced by exclosure age. The relatively large increase in soil carbon storage, soil $\mathrm{N}$ and $\mathrm{P}$ content, and the strong increase in plant species richness in the first five years may have resulted from the sizable carbon input derived from grass and forb biomass, from reduced soil erosion through improved ground cover, and from relatively slow decomposition under drier and cooler climate. Prohibition of grass harvesting during the first three to five years improved under-canopy cover, which could reduce the erosive impact of raindrops and consequently soil erosion. The relatively drier and cooler climate could also restrict decomposition of organic matter, which consequently may favour accumulation of soil carbon. The relatively slow increase of 
TABLE 5: Temporary certified emission reduction (tCER) units $\left(\mathrm{MgCO}_{2} \mathrm{ha}^{-1}\right)$ and soil nutrient stocks $\left(\mathrm{Mg} \mathrm{ha}^{-1}\right)$ in relation to exclosure duration.

\begin{tabular}{|c|c|c|c|c|c|c|}
\hline Year & 5 & 10 & 15 & 20 & 25 & 30 \\
\hline \multicolumn{7}{|c|}{ tCER units $\left(\mathrm{Mg} \mathrm{CO}_{2} \mathrm{ha}^{-1}\right)$} \\
\hline & \multirow[t]{4}{*}{117} & 117 & 117 & 117 & 117 & \\
\hline & & 38 & 38 & 38 & 38 & \\
\hline & & & 11 & 11 & 11 & \\
\hline & & & & 80 & 80 & \\
\hline Total & 117 & 155 & 166 & 246 & 246 & \\
\hline \multicolumn{7}{|c|}{ Total soil nitrogen stocks $\left(\mathrm{Mg} \mathrm{ha}^{-1}\right)$} \\
\hline & \multirow[t]{4}{*}{2.1} & 2.1 & 2.1 & 2.1 & 2.1 & 2.1 \\
\hline & & 1.4 & 1.4 & 1.4 & 1.4 & 1.4 \\
\hline & & & 1.7 & 1.7 & 1.7 & 1.7 \\
\hline & & & & 2.7 & 2.7 & 2.7 \\
\hline Total & 2.1 & 3.5 & 5.2 & 7.9 & 7.9 & 7.9 \\
\hline \multicolumn{7}{|c|}{ Available phosphorous stocks $\left(\mathrm{Mg} \mathrm{ha}^{-1}\right)$} \\
\hline & \multirow[t]{4}{*}{0.02} & 0.02 & 0.02 & 0.02 & 0.02 & 0.02 \\
\hline & & 0.00 & 0.00 & 0.00 & 0.00 & 0.00 \\
\hline & & & 0.01 & 0.01 & 0.01 & 0.01 \\
\hline & & & & 0.01 & 0.01 & 0.01 \\
\hline Total & 0.02 & 0.02 & 0.03 & 0.04 & 0.04 & 0.04 \\
\hline
\end{tabular}

TABLE 6: Benefits, costs, and net present value of exclosure establishment and crop production over a period of 30 years.

\begin{tabular}{|c|c|c|c|}
\hline Ecological benefits & Present value benefit (US\$ ha ${ }^{-1}$ ) & Present value cost $\left(\mathrm{US} \$ \mathrm{ha}^{-1}\right)$ & Net present value (US\$ $\mathrm{ha}^{-1}$ ) \\
\hline & \multicolumn{3}{|c|}{ Exclosure establishment } \\
\hline Ecosystem carbon storage & 992 & 0.0 & 992 \\
\hline \multicolumn{4}{|l|}{ Soil nutrients storage } \\
\hline (i) Total nitrogen & 2173 & 0.0 & 2173 \\
\hline (ii) Available phosphorous & 23 & 0.0 & 23 \\
\hline Subtotal & 3188 & 0.0 & 3188 \\
\hline Grass production & 255 & $372^{\mathrm{a}}$ & -117 \\
\hline Grand total & 3443 & 372 & 3071 \\
\hline \multicolumn{4}{|l|}{ Crop production } \\
\hline (i) Barley & 2601 & 1386 & 1215 \\
\hline (ii) Wheat & 3609 & 1376 & 2234 \\
\hline (iii) Teff & 3504 & 1418 & 2086 \\
\hline
\end{tabular}

${ }^{\mathrm{a}}$ This cost represents the payment for guards.

regulating ecosystem services from 5 years to 15 years of exclosure establishment was possibly a manifestation of vegetation succession and of the partial removal of organic matter input through harvesting of grass and forb biomass. Other studies conducted in the highlands and lowlands of Ethiopia have also shown that herbaceous/grass biomass and diversity decrease while shrub and tree abundances increase with exclosure age $[39,40]$. The substantial increase in soil carbon under 20-year exclosures could be due to increase in carbon input under increasingly shrub- and treevegetated areas and an increasing effect on preventing soil erosion.

The positive correlations of soil carbon and soil $\mathrm{N}$ and $\mathrm{P}$ contents in exclosures with woody biomass, vegetation canopy cover, and exclosure age support the influence of carbon input from vegetation in enhancing soil carbon and $\mathrm{N}$ and $\mathrm{P}$ contents. Other studies have also reported increasing soil carbon and soil nutrient contents along with increasing plant species and aboveground biomass [41-44]. The increase in canopy cover with exclosure age could also reduce runoff and sediment-associated losses of soil organic carbon, $\mathrm{N}$, and $\mathrm{P}$ [26]. The positive correlations of soil carbon and nutrients with precipitation and clay content indicate the importance of moisture availability in vegetation restoration as well as the importance of clay in conserving moisture, nutrients and soil carbon. This was also supported by the positive correlation between clay content and available soil moisture content (calculated using pedotransfer function; [45]) in the exclosures $(r=0.64, P<0.01)$. The negative correlations of soil carbon and nutrients with bulk density, stone cover 


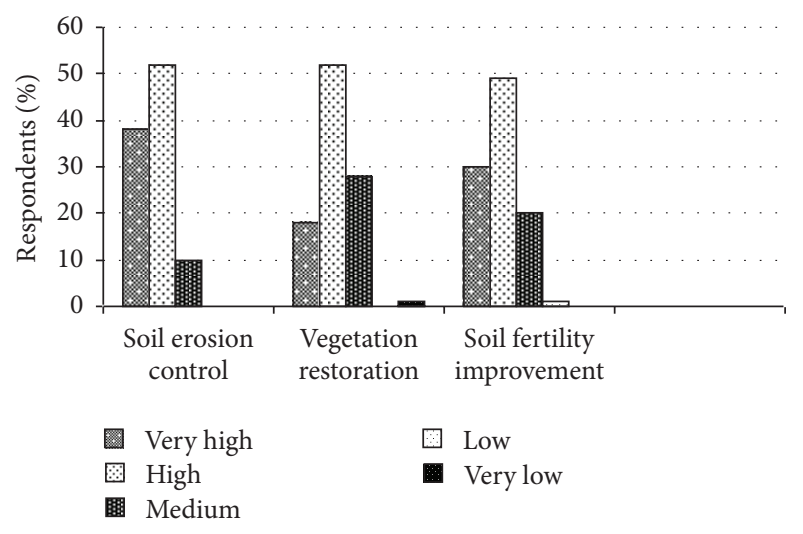

FIGURE 3: Local communities evaluation on the effectiveness of exclosures to restore degraded soils and vegetation $(n=90)$. Very high refers to a score of 5 out of 5 ; high $-4 / 5$; medium $-3 / 5$; low$2 / 5$; and very low-1/5.

and slope illustrate the negative effects of land degradation in general and soil erosion in particular on regulating ecosystem services.

Landscape position affected vegetation composition as illustrated by the higher plant species richness and diversity in upper slopes compared to foot slopes independent of exclosures age. The observed landscape effect is the result of the lower vegetation canopy cover at the upper slopes, which may favor the establishment of new species. In the Ethiopian highlands, Lemenih and Itanna [43] reported that canopy closure of tree plantations had a negative effect in the species richness of colonizing woody species. The higher aboveground biomass of foot slopes compared to the upper slopes at each exclosure age can probably be explained by the more favorable growth conditions (higher soil nutrient and moisture content) on the foot slopes compared to the mid and upper slopes [46]. Higher growth rates will lead to earlier canopy closure, which prohibits further establishment of pioneer species.

A comparison of the figures in Table 6 demonstrates that NPV from all ecosystem services of exclosures is 837 US \$, that is, $28 \%$ higher than wheat production, the best landuse alternative. This higher NPV from exclosures can be achieved in case that higher financial net return can be realized from soil nutrients and carbon storage. Concerning nitrogen, it has to be considered that the accumulated storage can hardly be traded on markets. It rather serves as a buffer for ensuring the provision of nutrients in the future. A conservative approach could deal with this aspect by recognizing only that lower amount of nitrogen, which is usually applied to alternative land uses per hectare and year. The respective annual quantities of $100 \mathrm{Kg} \mathrm{ha}^{-1}$ would add up to far smaller financial impact, that is, costs saved by soil nutrients restoration. However, this calculation would neglect the insurance component of exclosures for nutrient availability in the future.

Related to tCER net benefit, which sums up to about $44 \%$ of the wheat production net benefit, it can be seen that taking into account carbon revenues only does not provide sufficient incentives to initiate the participation of land managers and local communities in the establishment of further exclosures. As this is the first time that the economic benefits of ecosystem carbon and soil nutrients stored after the establishment of exclosures are evaluated, it is hardly possible to compare the results with other studies conducted in the region. Earlier studies that show the economic importance of exclosures were restricted to the revenues from grass production, fuel wood, and other non wood forest products such as the production of frankincense from Boswellia papyrifera [47, 48]. Although these studies do not include revenues from ecosystem carbon and soil nutrients restored in exclosures, they show the substantial economic impact of exclosures in addition to the ecological importance. There are some studies that evaluated the costs and benefits of sequestering carbon through different land uses; however, most of the studies deal with the economics of carbon sequestration achieved through afforestation and reforestation and are additionally located in the humid tropics $[49,50]$.

The results of the present study show that there are good opportunities to mobilize the local communities in the efforts to restore degraded lands through exclosure establishment as the majority of the respondents have a positive perception about the effectiveness of exclosures to restore degraded soils and vegetation (Figure 3). A similar result was reported from case study conducted on exclosures established in the central and northern highlands of Ethiopia [51]. The variation in perception among the respondents concerning the effectiveness of exclosures to restore degraded soils and vegetation can be explained by either the difference in exposure or understanding of their environment [52]. Furthermore, the perception of the local communities concerning the effectiveness of exclosures to restore degraded soils and vegetation does not seem to be influenced by the location of the agricultural lands and exclosures, as we observed only slight variation on the perception of respondents living near and far from exclosures.

Although the local communities have a positive perception and feel that they benefit from exclosures, they also expressed concerns for the negative impacts of exclosures such as reduction of fuel wood availability and grazing areas for their livestock grazing. This concern should be addressed because (1) the farming system in the study area is labor intensive and involves the use of livestock traction power, (2) livestock production is an important source of income and wealth, and (3) the local communities use fuel wood to meet their household energy demand. These results indicate that further expansion of exclosures in the near future could face resistance from local communities in case their direct and indirect benefits will not be transferred into payments for the respective ecosystem services.

The present study was entirely focused on the highlands of Ethiopia suggesting that the results may not be directly applied to other parts of the country such as the lowland and midlands. This is because the highlands and other parts of the country are different in biophysical and socio-economic settings. Thus, further study will be required to investigate the effectiveness of exclosures in enhancing ecosystem services in the lowlands. 


\section{Conclusions}

The results of the present study confirm that establishment of exclosures on degraded communal grazing lands in the Northern highlands of Ethiopian is a viable option to restore ECS, soil properties and nutrients and degraded native vegetation. The study also showed that the change in ECS, soil properties, and nutrients and vegetation composition following the establishment of exclosures can be explained by using easily measurable biophysical and management-related indicators. Such information is necessary for establishment of baseline information for carbon sequestration projects, for evaluation of whether exclosure establishment should be expanded, and for policy makers to take into account the value of exclosures in their management decisions. Further, if direct and indirect benefits are taken into account, exclosures are ecologically and economically advantageous and competitive to the other land-use alternatives such as crop production. Our results show that consideration of exclosures as CDM projects and thereby generating financial compensation to support the local communities in their effort to restore degraded lands might be a way to increase benefits for local communities. The findings of the present study provide important information for local decision makers, which might enhance the establishment and management of exclosures that are ecologically sound, economically profitable, and widely accepted by the local communities in the northern highlands of Ethiopia.

\section{References}

[1] MEA, Millennium Ecosystem Assessment: Ecosystems and Human Well-Being-A Framework for Assessment, World Resources Institute, Washington, DC, USA, 2003.

[2] J. A. Foley, R. DeFries, and G. P. Asner, "Global consequences of land use," Science, vol. 309, pp. 570-574, 2005.

[3] P. Falkowski, R. J. Scholes, E. Boyle et al., "The global carbon cycle: a test of our knowledge of earth as a system," Science, vol. 290, no. 5490, pp. 291-296, 2000.

[4] W. Mekuria and E. Aynekulu, "Exclosure land management for restoration of the soils in degraded communal grazing lands in northern highlands of Ethiopia," Land Degradation and Development, 2011.

[5] B. Nedessa, J. Ali, and I. Nyborg, Exploring Ecological and Socio-Economic Issues for the Improvement of Area Enclosure Management: a Case Study from Ethiopia, DCG (Drylands Coordination Group), Oslo, Norway, 2005.

[6] K. Descheemaeker, J. Nyssen, J. Rossi et al., "Sediment deposition and pedogenesis in exclosures in the Tigray highlands, Ethiopia," Geoderma, vol. 132, no. 3-4, pp. 291-314, 2006.

[7] K. Descheemaeker, B. Muys, J. Nyssen et al., "Litter production and organic matter accumulation in exclosures of the Tigray highlands, Ethiopia," Forest Ecology and Management, vol. 233, no. 1, pp. 21-35, 2006.

[8] M. Yami, W. Mekuria, and M. Hauser, "The effectiveness of village bylaws in sustainable management of communitymanaged exclosures in Northern Ethiopia," Sustainability Science, vol. 8, pp. 73-86, 2013.
[9] N. Chisholm, "Community-based natural resource management in Tigray, Northern Ethiopia," The World Bank/WBI's CBNRM Initiative, Washington, DC, USA, 1998.

[10] B. Gebremedhin, J. Pender, and G. Tesfay, "Community natural resource management: the case of woodlots in Northern Ethiopia," Environment and Development Economics, vol. 8, no. 1, pp. 129-148, 2003.

[11] G. Haile, Effect of exclosure on environment and its socio economic contributions to local people: in the case study of halla exclosure, Tigray, Ethiopia [M.S. thesis], Norwegian University of Life Science, Trondheim, Norway, 2012.

[12] W. Mekuria, E. Veldkamp, M. Haile, K. Gebrehiwot, B. Muys, and J. Nyssen, "Effectiveness of exclosures to control soil erosion and local community perception on soil erosion in Tigray, Ethiopia," African Journal of Agricultural Research, vol. 4, no. 4, pp. 365-377, 2009.

[13] W. Mekuria, "Conversion of communal grazing lands into exclosures restored soil properties in the semi-arid lowlands of Northern Ethiopia," Arid Land Research and Management, vol. 27, pp. 153-166, 2013.

[14] W. Mekuria and E. Veldkamp, "Restoration of native vegetation following exclosure establishment on communal grazing lands in Tigray, Ethiopia," Applied Vegetation Science, vol. 15, no. 1, pp. 71-83, 2012.

[15] W. Mekuria, E. Veldkamp, M. Tilahun, and R. Olschewski, "Economic valuation of land restoration: the case of exclosures established on communal grazing lands in Tigray, Ethiopia," Land Degradation and Development, vol. 22, no. 3, pp. 334-344, 2011.

[16] W. Mekuria, E. Veldkamp, M. O. Corre, and M. Haile, "Restoration of ecosystem carbon stocks following exclosure establishment in communal grazing lands in Tigray, Ethiopia," Soil Science Society of America Journal, vol. 75, no. 1, pp. 246-256, 2011.

[17] F. Yimer, S. Ledin, and A. Abdelkadir, "Changes in soil organic carbon and total nitrogen contents in three adjacent land use types in the Bale Mountains, south-eastern highlands of Ethiopia," Forest Ecology and Management, vol. 242, no. 2-3, pp. 337-342, 2007.

[18] E. Veldkamp, "Organic carbon turnover in three tropical soils under pasture after deforestation," Soil Science Society of America Journal, vol. 58, no. 1, pp. 175-180, 1994.

[19] T. Sorensen, A Method of Establishing Groups of Equal Amplitude in Plant Sociology Based on Similarity of Species Content, vol. 5 of Det Kong. Danske Videnskabernes Selskab, Biologiske Skrifter, Copenhagen, Denmark, 1948.

[20] C. E. Shannon, "A mathematical theory of communication," Bell System Technical Journal, vol. 27, pp. 379-423, 1948.

[21] C. Hoff, S. Rambal, and R. Joffre, "Simulating carbon and water flows and growth in a Mediterranean evergreen Quercus ilex coppice using the FOREST-BGC model," Forest Ecology and Management, vol. 164, no. 1-3, pp. 121-136, 2002.

[22] P. Snowdon, J. Raison, H. Keith et al., "Protocol for sampling tree and stand biomass. National carbon accounting system technical report," Australian greenhouse office, No. 31, 2002.

[23] UNFCCC, "Development and transfer of technologies," Report of the UNFCCC workshop on enabling environments for technology transfer, Ghent, Belgium, April 2003.

[24] R. Olschewski, P. C. Benítez, G. H. J. de Koning, and T. Schlichter, "How attractive are forest carbon sinks? Economic insights into supply and demand of Certified Emission Reductions," Journal of Forest Economics, vol. 11, no. 2, pp. 77-94, 2005. 
[25] B. Babulo, B. Muys, and E. Mathijs, "Economic valuation methods of forest rehabilitation in exclosures," Journal of Drylands, vol. 1, pp. 65-170, 2006.

[26] G. Girmay, B. R. Singh, J. Nyssen, and T. Borrosen, "Runoff andsediment-associated nutrient losses under different land uses in Tigray, Northern Ethiopia," Journal of Hydrology, vol. 376, no. 1-2, pp. 70-80, 2009.

[27] A. Verdoodt, S. M. Mureithi, L. Ye, and E. Van Ranst, "Chronosequence analysis of two enclosure management strategies in degraded rangeland of semi-arid Kenya," Agriculture, Ecosystems and Environment, vol. 129, no. 1-3, pp. 332-339, 2009.

[28] K. Mamo, Enclosure as a viable option for rehabilitation of degraded lands and biodiversity conservation: the case of Kallu Woreda, Southern Wello [M.S. thesis], Addis Ababa University, Addis Ababa, Ethiopia, 2008.

[29] A. Tsetargachew, Area closure as a strategy for land management: a case study at Kelala Dalacha enclosure in the central rift valley of Ethiopia [M.S. thesis], Addis Ababa University, Addis Ababa, Ethiopia, 2008.

[30] T. Mengistu, D. Teketay, H. Hulten, and Y. Yemshaw, "The role of enclosures in the recovery of woody vegetation in degraded dryland hillsides of central and northern Ethiopia," Journal of Arid Environments, vol. 60, no. 2, pp. 259-281, 2005.

[31] M. H. Abebe, G. Oba, A. Angassa, and R. B. Weladji, "The role of area enclosures and fallow age in the restoration of plant diversity in northern Ethiopia," African Journal of Ecology, vol. 44, no. 4, pp. 507-514, 2006.

[32] M. Yami, K. Gebirehiwot, M. Stein, and W. Mekuria, "Impact of area enclosures on density, diversity, and population structure of woody species: the Case of May Batati-Douga Tembien, Tigray, Ethiopia," Ethiopian Journal of Natural Resources, vol. 8, pp. 99-121, 2006.

[33] E. Berhane, D. Teketay, and P. Barklund, "Enclosures to enhance woody species diversity in the drylands of Tigray," East African Journal of Science, vol. 1, pp. 136-147, 2007.

[34] A. N. Muchiru, D. Western, and R. S. Reid, "The impact of abandoned pastoral settlements on plant and nutrient succession in an African savanna ecosystem," Journal of Arid Environments, vol. 73, no. 3, pp. 322-331, 2009.

[35] G. Hosseinzadeh, H. Jalilvand, and R. Tamartash, "Short time impact of enclosure on vegetation cover, productivity and some physical and chemical soil properties," Journal of Applied Sciences, vol. 10, no. 18, pp. 2001-2009, 2010.

[36] A. Verdoodt, S. M. Mureithi, and E. Van Ranst, "Impacts of management and enclosure age on recovery of the herbaceous rangeland vegetation in semi-arid Kenya," Journal of Arid Environments, vol. 74, pp. 1066-1073, 2010.

[37] G. Zenebe, Household fuel consumption and resource use in rural-urban Ethiopia [Ph.D. thesis], Wageningen University, 2007.

[38] CSA (Central Statistical Agency of Ethiopia), "Summary and statistical report of the 2007 population and housing Census. Addis Ababa, Ethiopia," 114 pages, 2008.

[39] T. Yayneshet, L. O. Eik, and S. R. Moe, "The effects of exclosures in restoring degraded semi-arid vegetation in communal grazing lands in northern Ethiopia," Journal of Arid Environments, vol. 73, no. 4-5, pp. 542-549, 2009.

[40] A. Angassa and G. Oba, "Effects of grazing pressure, age of enclosures and seasonality on bush cover dynamics and vegetation composition in southern Ethiopia," Journal of Arid Environments, vol. 74, no. 1, pp. 111-120, 2010.
[41] R. Lal, "World cropland soils as a source or sink for atmospheric carbon," Advances in Agronomy, vol. 71, pp. 145-191, 2001.

[42] D. Solomon, F. Fritzsche, J. Lehmann A, M. Tekalign, and W. Zech, "Soil organic matter dynamics in the subhumid agroecosystems of the Ethiopian highlands: evidence from natural 13C abundance and particle-size fractionation," Soil Science Society of America Journal, vol. 66, no. 3, pp. 969-978, 2002.

[43] M. Lemenih and F. Itanna, "Soil carbon stocks and turnovers in various vegetation types and arable lands along an elevation gradient in southern Ethiopia," Geoderma, vol. 123, no. 1-2, pp. 177-188, 2004.

[44] M. Lemenih, E. Karltun, and M. Olsson, "Soil organic matter dynamics after deforestation along a farm field chronosequence in southern highlands of Ethiopia," Agriculture, Ecosystems and Environment, vol. 109, no. 1-2, pp. 9-19, 2005.

[45] M. Van den Berg, E. Klamt, L. P. van Reeuwijk, and W. G. Sombroek, "Pedotransfer functions for the estimation of moisture retention characteristics of Ferralsols and related soils," Geoderma, vol. 78, no. 3-4, pp. 161-180, 1997.

[46] W. Mekuria, E. Veldkamp, M. Haile, J. Nyssem, B. Muys, and K. Gebirehiwot, "Effectiveness of exclosures to restore degraded soils as a result of overgrazing in Tigray, Ethiopia," Journal of Arid Environments, vol. 69, no. 2, pp. 270-284, 2007.

[47] M. Tilahun, R. Olschewski, C. Kleinn, and K. Gebrehiwot, "Economic analysis of closing degraded Boswellia papyrifera dry forest from human interventions-a study from Tigray, Northern Ethiopia," Forest Policy and Economics, vol. 9, no. 8, pp. 996-1005, 2007.

[48] B. Babulo, B. Muys, F. Nega et al., "The economic contribution of forest resource use to rural livelihoods in Tigray, Northern Ethiopia," Forest Policy and Economics, vol. 11, no. 2, pp. 109-117, 2009.

[49] R. Olschewski and P. C. Benítez, "Secondary forests as temporary carbon sinks? The economic impact of accounting methods on reforestation projects in the tropics," Ecological Economics, vol. 55, no. 3, pp. 380-394, 2005.

[50] R. Olschewski and P. Benítez, "Optimizing joint production of timber and carbon sequestration of afforestation projects," Journal of Forest Economics, vol. 16, no. 1, pp. 1-10, 2010.

[51] T. Mengistu, D. Teketay, H. Hultén, and Y. Yemshaw, "The role of communities in closed area management in Ethiopia," Mountain Research and Development, vol. 25, no. 1, pp. 44-50, 2005.

[52] B. Legesse and L. Drake, "Determinants of smallholder farmers' perceptions of risk in the Eastern Highlands of Ethiopia," Journal of Risk Research, vol. 8, no. 5, pp. 383-416, 2005. 

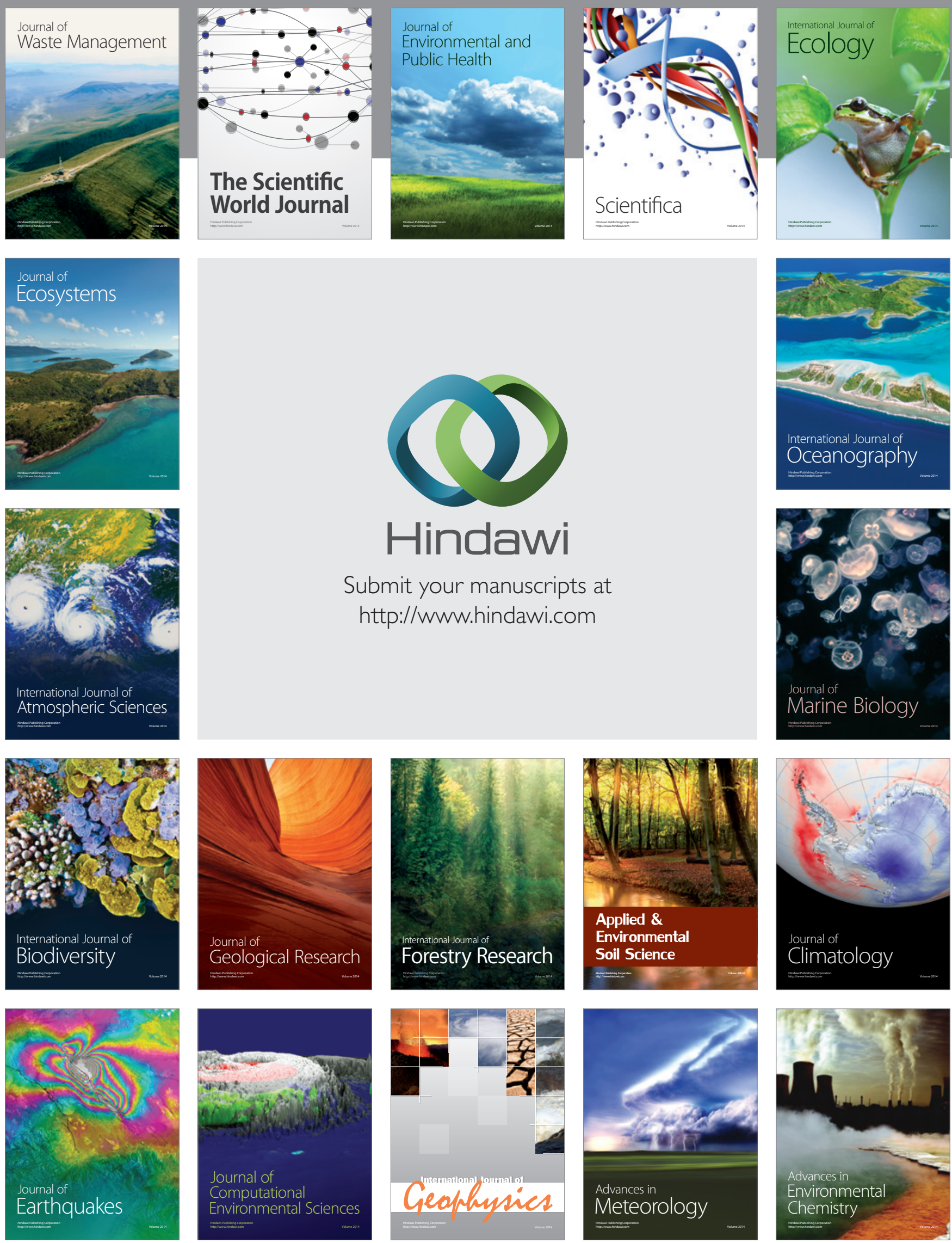